\title{
KESEJAHTERAAN PEMEGANG SAHAM BIDDER DALAM JANGKA PANJANG PASCA MERGER DAN AKUISISI
}

\author{
Permata Dian Pratiwi
}

Universitas Ahmad Dahlan
permatadianp@yahoo.com

\begin{abstract}
The purpose of this research is to find how merger and acquisition create value for stakeholder at long-term post of an event. Testing of this welfare cannot be measured only in the short-term to avoid the bubble effect. Merger and acquisition conducted to obtain benefits or synergies. So the hypothesis proposed in this study is there a statistically significant positive value for bidding after the merger in the long-term. But the results of this study indicate that the fallout. The result showed statistically significant that the merger and acquisition do not provide for the welfare of shareholders bidder after the merger in the long-term. The research result supports several previous studies.
\end{abstract}

Keywords: merger, acquisition, bidder, target, value, long-term

\section{PENDAHULUAN}

Perusahaan-perusahaan di Indonesia berusaha memperbesar bisnisnya dengan melakukan mergerdanakusisi. Mergerdanakuisisi dilakukan dapat juga dikarenakan motivasi lain, seperti adanya kepentingan pribadi manajer yang bersangkutan. Menurut Komisi Pengawas Perlindungan Usaha di Indonesia (www.kppu. co.id), data perusahaan yang melakukan merger dan akuisisi semakin bertambah, bahkan tidak hanya perusahaan lokal tetapi juga perusahaan asing. Adanya partisipasi perusahaan asing tersebut menunjukkan Indonesia cukup dapat dipercaya untuk dijadikan tujuan investasi. Dengan merger dan akuisisi diharapkan dapat memberikan manfaat bagi pihak-pihak yang bersangkutan.

Perusahaan melakukan merger dan akuisisi dimotivasi dengan berbagai hal, baik yang logis maupun tidak logis. Tujuan merger
\end{abstract}

dan akuisisi seharusnya untuk menghasilkan sinergi, dimana perusahaan-perusahaan tersebut akan lebih baik bergabung daripada hanya menjalankan usahanya sendiri. Tetapi tidak semua perusahaan yang bergabung akan mencapai hasil yang lebih baik. Hasil penelitian Scaik, Spronk \& Steenbeek (2011) menemukan bahwa merger tidak terlihat menciptakan kesejahteraan bagi pemegang saham dengan sampel perbankan di Jepang. Moeller, Schilengemann, \& Stulz (2005) menemukan bahwa pemegang saham perusahaan bidder rugi 12 sen sekitar pengumuman akuisisi untuk setiap dollar yang dikeluarkan pada akuisisi dengan total kerugian \$240 juta dari tahun 1996 sampai 2001. Hasil penelitian Moeller et al. (2005) tersebut menyatakan bahwa perusahaan yang melakukan akuisisi mengalami kinerja buruk setelahnya. Hal tersebut dikarenakan pada periode tersebut terjadi gelombang merger besar-besaran yang disebabkan kesalahan valuasi harga saham perusahaan bubble yang secara 
ekstrim terlalu tinggi. Duchin \& Schmidt (2013) menyatakan bahwa gelombang merger mungkin mengembangkan perilaku agency-driven, yang mana kepentingan manajer dapat mengarahkan pada merger yang buruk.

Terkadang kesalahan valuasi memotivasi para manajer perusahaan tersebut untuk memanfaatkan kondisi yang ada untuk kepentingan mereka sendiri sesuai dengan teori market timing. Para manajer mengantisipasi kesempatan untuk diakuisisi supaya tidak kehilangan manfaat pribadi dari pengontrolannya terhadap perusahaan jika perusahaan diakuisisi (Gorton, et al, 2009). Adanya kesalahan valuasi yang tinggi, perusahaan-perusahaan akan terlihat lebih memiliki kekuatan dan menarik untuk melakukan merger dan akuisisi, sehingga para manajer memutuskan merger dan akuisisi sebelum pasar mengetahui adanya kesalahan valuasi harga saham tersebut (Savor \& Lu, 2009). Tetapi tidak semua keputusan merger dan akuisisi dimotivasi karena kepentingan manajer. Merger dan akuisisi yang baik dimotivasi sesuai dengan teori neoklasik, seperti menambah skala ekonomi perusahaan.

Teori neoklasik memprediksi bahwa suatu kombinasi baru akan menjadi lebih produktif daripada hanya bagian-bagian sendiri, yang berarti manfaat sinergi akan direalisasikan (Ahern \& Weston, 2007). Seperti yang diketahui pada umumnya, manfaat akuisisi biasanya dirasakan oleh perusahaan target daripada perusahaan bidder. (Antoniou, et al, 2007) menguji pengaruh kesejahteraan pemegang saham baik jangka pendek dan jangka panjang dari perusahaan bidder dan target. Kesimpulan dari penelitian mereka, pengaruh kesejahteraan pemegang saham bidder tidak bisa didasarkan pada event study jangka pendek.

Hasil penelitian Savor \& Lu (2009) menemukan bahwa overvalue perusahaan menciptakan nilai bagi pemegang saham bidder dalam jangka panjang. Hasil penelitian ini juga mendukung penelitian Antoniou et al. (2007) untuk membuktikan adanya kesejahteraan bagi pemegang saham untuk jangka panjang, bukan dilihat dari jangka pendek saja. Bukti penelitian Wang \& Xie (2009) menyatakan bahwa target akuisisi yang dikelola dengan buruk dengan bidder yang baik akan menciptakan nilai yang lebih baik. Membuktikan bahwa apabila motivasi yang baik dari merger dan akuisisi dan adanya integrasi yang baik, maka keputusan merger dan akuisisi akan menghasilkan manfaat bagi pihakpihak yang bersangkutan sesuai dengan teori neoklasik.

Dari penjelasan diatas, tampak kesenjangan darihasil-hasilpenelitian sebelumnya dan juga teori-teori yang memotivasi merger dan akuisisi. Penelitian ini dimaksudkan untuk menguji pengaruh merger dan akuisisi terhadap kesejahteraan pemegang saham perusahaan bidder dalam jangka panjang. Penjelasan mengenai motivasi merger dan akuisisi yang diajukan teori neoklasik berbeda dengan teori market timing yang merupakan bagian dari teori perilaku. Hal ini menjadi menarik karena untuk mengetahui lebih jauh bagaimana merger dan akuisisi yang dapat menciptakan nilai.

\section{REVIEW LITERATUR DAN HIPOTESIS}

\section{Merger dan Akuisisi}

Merger merupakan penggabungan dua perusahaan atau lebih untuk membentuk satu perusahaan (Brigham \& Houston, 2007). Merger dan akuisisi merupakan transfer kendali dari satu kelompok investor ke kelompok investor lain. Sebenarnya akuisisi itu merupakan salah satu bentuk merger. Jika salah satu pihak kekuatan yang lebih besar dan yang lain menjadi target maka terjadilah proses akuisisi. Dalam Hanafi (2004), pada akuisisi perusahaan yang diambil alih tersebut kemudian menggunakan nama baru, sedangkan pada merger, perusahaan yang diambil alih memakai nama perusahaan yang 
mengakuisisi. Pada umumnya perusahaan yang mengakuisisi meupakan perusahaan yang lebih besar dibandingkan perusahaan yang diakuisisi. Menurut Hanafi (2004), terdapat beberapa langkah dalam melakukan merger dan akuisisi. Pertama adalah proses strategi dimana dibutuhkan analisisi dalam memutuskan kelayakan merger dan akuisisi. Setelah hasil analisis menyatakan merger dan akuisisi layak dijalankan maka langkah kedua adalah proses transaksi. Setelah adanya transaksi kemudian keputusan tersebut diimplementasikan. Proses ketiga ini lah tantangan baru bagi perusahaanperusahaan yang melakukan merger dan akuisisi. Menggabungkan dua perusahaan atau lebih ini tidak semudah melakukan proses transaksi. Setiap perusahaan memiliki budaya dan lingkungan kerja yang berbeda. Jika perusahaan sukses dalam meleburkan keseluruhan yang ada, tidak hanya dalam sisi kepemilikan dan nama saja, maka merger dan akuisisi akan sukses membentuk sinergi positif.

\section{Motivasi Merger dan Akuisisi}

Terdapat beberapa hal yang memotivasi perusahaan untuk melakukan merger dan akuisisi menurut Hanafi (2014), yaitu:

1. Sinergi dan skala ekonomi

Peningkatan skala ekonomi dengan berpandangan lebih besar lebih baik dapat terjadi jika merger dan akuisisi terinntegrasi dengan baik atau menciptakan sinergi. Pertumbuhan tanpa diikuti peningkatan sinergi tidak aka nada pengaruh positif terhadap pemegang saham

2. Pengendalian

Merger dan akuisisi dapat dimotivasi untuk mengendalikan jalur produksi atau distribusi. Perusahaan dapat merger atau mengakuisisi perusahaan yang menjadi suppliernya untuk mengendalikan biaya produksi atau biaya pasokan perusahaan. Aktivitas ini disebut dengan merger vertikal backward. Perusahaan juga dapat memutuskan untuk melakukan merger vertikal forward. Aktivitas ini dilakukan dengan merger atau mengakuisisi perusahaan yang mendistribusikan produk sehingga dapat mengedalikan harga produk perusahaan. Aktivitas merger ini diharapkan dapat membuat perusahaan beroperasi seefisien mungkin. Jika memiliki produksi dan atau distribusi sendiri dinilai lebih menguntungkan perusahaan daripada perusahaan bergantung pada perusahaan lain, sebaiknya perusahaan memutuskan untuk merger atau akuisisi perusahaan tersebut.

3. Pajak

Perusahaan besar yang biasanya memiliki laba yang tinggi akan dikenakan pajak yang tinggi juga. Penghematan pajak dapat dilakukan jika perusahaan mengakuisisi perusahaan yang mempunyainkerugian cukup besar. Akuisisi dapat dibiayai dengan hutang sehingga terjadi restrukturisasi asset dan perusahaan besar tadi akan memiliki hutang yang cukup besar. Laba perusahaan harus digunakan untuk membayar bunga pinjaman sebelum membayar pajak. Pajak yang dibayarkan perusahaan akan lebih kecil daripada sebelum mengakuisisi dan terjadi lah penghematan pajak.

4. Menggabungkan sumber daya

Untuk memiliki sumber daya yang saling melengkapi perusahaan dapat melakukan merger dan akuisisi horizontal. Contoh merger dan akuisisi horizontal di Indonesia adalah Trans TV dan Trans 7 (Kompas) yang bergerak dalam bidang pertelevisian. Keduanya saling melengkapi dalam menawarkan program acara yang ditayangkan ke masyarakat.

5. Menghilangkan ketidakefisienan

Ketidakefisienan pada manajemen perusahaan membuat perusahaan tidak dapat berkembang. Ketidakefisienan ini dapat juga terjadi ketika perusahaan tidak mampu mengikuti perkembangan teknologi. Perusahaan yang tidak efisien seperti ini dapat memutuskan 
untuk menggabungkan dengan perusahaan yang memiliki kompetensi tinggi. Perusahaan yang manajemennya tidak kompeten dapat merger atau diakusisi dengan perusahaan dengan manajemen yang kompeten sehingga dapat menghilangkan manajer yang tidak kompeten. Mengembangkan teknologi senidri akan dinilai lebih mahal karena membutuhkan biaya tinggi dan waku yang lama. Perusahaan akan lebih mudah untuk menghilangkan ketidakefisienan pada teknologi dengan bergabung ke perusahaan yang teknologinya maju.

\section{Teori Neoklasik dari Merger dan Akuisisi}

Para akademisi dan para praktisi telah menjalani uji empiris untuk mengembangkan teori-teori tentang merger dan akuisisi. Ahern \& Weston (2007) menyatakan bahwa teori neoklasik (the good) memiliki kekuatan penjelasan lebih dibandingkan teori redistribusi (the bad), dan teori perilaku (the ugly) yang mendasari merger dan akuisisi. Secara tradisional, merger dan akuisisi didefinisikan menjadi pembelian perusahaan atau asset spesifik oleh perusahaan lain. Teori ekonomi neoklasik memprediksi bahwa suatu kombinasi baru akan menjadi lebih produktif daripada hanya bagian-bagian sendiri, berarti keuntungan sinergi akan direalisasikan. Salah satu manfaat kombinasi tersebut adalah kemampuan yang dapat ditambah lebih cepat daripada program-progam internal perusahaan. Perubahan lingkungan secara cepat (seperti perubahan teknologi, globalisasi, deregulasi dan lain-lain) menciptakan potensial peran yang lebih besar untuk merger dan akuisisi (Ahern \& Weston, 2007). Perusahaan lebih cepat menyesuaikan adanya perubahan dan inovasi di lingkungan bisnisnya dengan melakukan merger dan akuisis dibandingkan harus memulai dengan program internal perusahaan. Program internal perusahaan untuk pengembangan teknologi, inovasi produk, dan pengembangan sumber daya yang lain dari perusahaan akan memerlukan waktu dan biaya yang sangat besar. Bahkan program internal tersbeut tidak menutup kemungkinan akan gagal dan membuat semakin tertinggal dari kemajuan eksternal bisnis perusahaan. Maka merger dan akusisi perusahaan lain yang telah memiliki keunggulan yang dicari perusahaan akan menjadi keputusan yang tepat bagi perusahaan bidder.

\section{Teori Redistribusi dari Merger dan Akuisisi}

Terdapat lima teori redistribusi yang dikategorikan oleh kelompok stakeholder dari suatu merger, yaitu tax gain untuk bidder, peningkatan kekuatan pasar, pemegang obligasi, pekerja, dan dana pensiun (Ahern \& Weston, 2007). Masing-masing kategori merupakan beberapa motivasi dalam melakukan merger dan akuisisi. Keuntungan bagi bidder dari merger dan akuisisi adalah dapat menghemat pengeluaran pajak. Apabila suatu perusahaan bidder memiliki laba yang tinggi maka pajak yang harus dibayarkan pun akan tinggi. Untuk menghemat pembayaran pajak, maka bidder akan mencari target perusahaan untuk diakuisisi. Selain untuk mengurangi pembayaran pajak, perusahaan bidder juga dapat berinvestasi pada perusahaan target. Merger dan akuisisi dapat meningkatan kekuatan pasar perusahaan bidder. Perusahaan dapat menguasai sektor hulu sampai hilir bidang bisnisnya dengan merger dan akuisisi. Misalnya perusahan yang produknya adalah kecap dapat mengusai harga dan suplai pasokan kedelai dari petani kedelai dengan membeli pertaniannya kemudian menyewakan lahan ke petani yang sudah ada. Dengan menguasai dari bahan mentah sampai distributor, perusahaan lebih mudah mengedalikan pasar bisnisnya.

\section{Teori Perilaku dari Merger dan Akuisisi}

Menurut Ahern \& Weston (2007), teori neoklasik dari merger menempatkan merger dan akuisisi untuk membantu perusahaan-perusahaan untuk menyesuaikan terhadap perubahan 
lingkungan atau memperluas kemampuannya. Dibawah teori neoklasik, pasar akan memberi reward pada merger yang membuat economic sense dan menghukum yang tidak membuat economic sense. Keuntungan merger akan diperoleh jika perusahaan melakukan merger dengan motivasi dan cara yang baik. Sedangkan hukuman atau kerugian akan diperoleh jika perusahaan tidak mampu mencapai tujuan merger dengan baik. Tujuan atau motivasi yang buruk akan menghasilkan sesuatu yang buruk juga untuk perusahaan. Empat teori perilaku merger yaitu hubris, kesalahan valuasi pasar, masalah agency dan integration, menganggap merger sebagai permulaan dari kekuatan ekonomi neoklasik. Keempat teori tersebut dalam teori neoklasik merupakan motivasi yang buruk untuk merger dan akuisisi. Perusahaan memanfaatkan adanya kesalahan penilaian pasar yang terlalu tinggi terhadap perusahaan untuk melakukan merger atau membiarkan perusahaan diakuisisi oleh bidding. Masalah agency juga merupakan hal buruk sebagai motivasi melakukan merger dan akuisisi. Adanya kesalahan valuasi pasar memunculkan kepentingan pribadi agen perusahaan atau manajer perusahaan untuk memperoleh keuntungan pribadi dengan merger dan akuisisi. Perusahaan yang terlihat baik di pasar ternyata kinerja sesungguhnya tidak sebaik yang terlihat. Perusahaaan bidder harus mengidentifikasi target sebelum memutuskan merger dan akuisisi untuk menghindari kerugian saham bubbles. Oleh karena itu teori redistribusi tidak disebut the bad tetapi the ugly. Sessuai dengan penjelasan sebelumnya, maka hipotesis hubris menyatakan bahwa pemegang saham bidding akan mengalami kerugian selama pengumuman merger dan akusisi (Ahern \& Weston, 2007).

\section{Pengaruh Pengumuman Merger dan Akuisisi}

Pasar dikatakan efisien apabila harga mencerminkaan informasi yang relevan dengan segera. Pengumuman keputusan merger dan akuisisi merupakan informasi yang relevan. Jika pasar efisien setengah kuat, pengumuman merger dan akuisisi tersebut akan segera direspon oleh pasar. Pengaruh pengumuman tersebut dapat direspon positif maupun negatif oleh pasar. Apabila pasar memandang keputusan tersebut akan memberikan manfaat dan prospek ke depannya, maka perusahaan-perusahaan tersebut akan menghasilkan abnormal return positif dan signifikan secara statistic seperti hasil penelitian Wang \& Xie (2009). Penelitian ini diharapkan sejalan dengan penelitian Wang \& Xie (2009), bahwa merger dan akuisisi akan memberikan pengaruh positif bagi kesejahteraan pemegang saham bidder dalam jangka panjang. Maka hipotesis yang dikembangkan dalam penelitian ini adalah:

$\mathrm{H}_{1}$ : terdapat pengaruh positif dan signifikan secara statistik antara pasca merger dan akuisisi dalam jangka panjang dan kesejahteraan bidding.

\section{METODE PENELITIAN}

\section{Populasi dan Sampel}

Populasi penelitian ini adalah perusahaan yang melakukan merger dan akuisisi yang terdaftar di Bursa Efek Indonesia. Pengambilan sampel penelitian ini dilakukan dengan pendekatan purposive sampling dengan kriteria: 1) Perusahaan yang terdafatar di Bursa Efek Indonesia yang melakukan merger dan akusisi antara tahun 2000 sampai dengan 2011. 2) Perusahaan memiliki tanggal pengumuman merger dan akuisisi yang jelas. 3) perusahaan menerbitkan laporan keuangan secara lengkap selama pengumuman merger dan setelah pengumuman merger dengan periode berakhir per 31 Desember. Periode yang dipakai dalam penelitian ini adalah dari tahun 2000 sampai dengan tahun 2014. Dari kriteria yang ditetapkan 
diperoleh jumlah sampel penelitian sebanyak 28 perusahaan. Daftar perusahaan sampel dapat dilihat pada tabel 1 .

\section{Teknik Pengumpulan Data}

Tabel 1

\section{Daftar Perusahaan Sampel}

\begin{tabular}{|c|c|c|c|}
\hline No. & $\begin{array}{c}\text { Kode } \\
\text { Perusahaan }\end{array}$ & Nama Perusahaan & $\begin{array}{c}\text { Tanggal } \\
\text { Pengumuman }\end{array}$ \\
\hline 1 & ETWA & PT. Eterindo Wahanatama, Tbk. & $27 / 03 / 2000$ \\
\hline 2 & SMAR & PT. Smart, Tbk. & $29 / 11 / 2000$ \\
\hline 3 & INDF & PT. Indofood Sukses Makmur, Tbk. & $5 / 1 / 2001$ \\
\hline 4 & STTP & PT. Siantar Top, Tbk. & $22 / 08 / 2001$ \\
\hline 5 & AALI & PT. Astra Agro Lestari, Tbk. & $10 / 2 / 2002$ \\
\hline 6 & MEDC & PT. Medco Energi International, Tbk. & $1 / 7 / 2002$ \\
\hline 7 & GGRM & PT. Gudang Garam, Tbk. & $3 / 7 / 2002$ \\
\hline 8 & AKRA & PT. Aneka Kimia Raya, Tbk. & $4 / 9 / 2003$ \\
\hline 9 & UNVR & PT. Unliever, Tbk. & $1 / 7 / 2004$ \\
\hline 10 & KLBF & PT. Kalbe Farma, Tbk. & $10 / 3 / 2005$ \\
\hline 11 & MITI & PT. Siwani Trimitra, Tbk. & $13 / 03 / 2006$ \\
\hline 12 & ADES & PT. Ades Waters Indonesia, Tbk. & $21 / 04 / 2006$ \\
\hline 13 & BUMI & PT. Bumi Resources, Tbk. & $16 / 06 / 2006$ \\
\hline 14 & TOTO & PT. Surya Toto Indonesia, Tbk. & $5 / 12 / 2006$ \\
\hline 15 & SMSM & PT. Selamat Sampurna, Tbk. & $4 / 1 / 2007$ \\
\hline 16 & FREN & PT. Mobile 8 Telecom, Tbk. & $31 / 05 / 2007$ \\
\hline 17 & TRST & PT. Trias Sentosa, Tbk & $3 / 7 / 2007$ \\
\hline 18 & BRPT & Barito Pacific, Tbk. & $9 / 7 / 2007$ \\
\hline 19 & UNTR & United Tractor, Tbk & $14 / 1 / 2008$ \\
\hline 20 & MTDL & Metrodata Electronics Tbk. & $22 / 5 / 2008$ \\
\hline 21 & SULI & Sumalindo Lestari Jaya, Tbk. & $6 / 6 / 2008$ \\
\hline 22 & RMBA & Bentoel Internasional Investama Tbk & $23 / 12 / 2009$ \\
\hline 23 & ASII & PT Astra International, Tbk. & $27 / 12 / 2010$ \\
\hline 24 & SOBI & PT Sorini Agro Asia Corporindo, Tbk & $2 / 3 / 2011$ \\
\hline 25 & ANTM & PT Aneka Tambang, Tbk & $18 / 5 / 2011$ \\
\hline 26 & JSMR & PT Jasa Marga (Persero), Tbk. & $10 / 6 / 2011$ \\
\hline 27 & EMTK & PT Elang Mahkota Teknologi & $28 / 6 / 2011$ \\
\hline 28 & KKGI & PT Resource Alam Indonesia, Tbk & $18 / 8 / 2011$ \\
\hline
\end{tabular}

Metode pengumpulan data penelitian ini dengan mengumpulkan data historis seperti harga saham bulanan perusahaan pada saat pengumuman dan setelah pengumuman merger dan akuisisi serta laporan keuangan perusahaan selama periode yang digunakan dalam penelitian ini. Sumber data dalam penelitian ini diperoleh dari Indonesian Capital Market Directory (ICMD), idx statistic, dan Bursa Efek Indonesia (BEI) di pojok BEI.

\section{Model Penelitian}

Model penelitian ini menggunakan model yang digunakan untuk menguji dampak aktivitas merger dan akuisisi terhadap kesejahteraan pemegang saham bidder dalam jangka panjang. Model ini merupakan model yang dikembangkan oleh Fama and French, yang digunakan oleh Savor \& Lu (2009) untuk menguji apakah merger menciptakan nilai bagi pemegang saham bidder dalam jangka panjang yang mana risiko premium, faktor ukuran dan book to market perusahaan dimasukkan sebagai variabel kontrol.

$$
\mathbf{R i}_{\mathbf{t}}=\alpha+\beta \mathbf{R p M}_{t}+\gamma \mathbf{S M B}_{\mathbf{t}}+\delta \mathbf{H M L}_{\mathbf{t}}+\mathbf{e}_{\mathrm{t}}
$$

Dengan penjelasan variabel sebagai berikut:

$\mathrm{Ri}_{\mathrm{t}} \quad$ : excess return portofolio pada bulan $\mathrm{t}$.

$\mathrm{RpM}_{\mathrm{t}}$ : risiko premium pada bulan $\mathrm{t}$.

$\mathrm{SMB}_{\mathrm{t}}$ : faktor ukuran pada bulan $\mathrm{t}$.

$\mathrm{HML}_{\mathrm{t}}$ : faktor book to market pada bulan $\mathrm{t}$.

$\mathrm{e}_{\mathrm{t}} \quad$ : error term pada bulan $\mathrm{t}$.

Pada model, untuk menguji kesejahteraan pemegang saham bidder dalam jangka panjang yang diperhatikan adalah nilai $\alpha$. Nilai $\alpha$ tersebut merupakan nila dari cumulative abnornmal return (CAR) yang menunjukkan kesejahteraan pemegang saham bidder dalam jangka panjang. Apabila nilai $\alpha>0$ dan signifikan secara statistik, maka merger dan akuisisi menciptakan nilai atau kesejahteraan pemegang saham bidder dalam jangka panjang. Sedangkan apabila nilai $\alpha<0$, maka merger dan akuisisi tidak menciptakan nilai atau kesejahteraan pemegang saham bidder dalam jangka panjang. 


\section{Definisi Operasional Variabel Penelitian}

Pada variabel penelitian ini terdiri dari variabel dependen, variabel independen dan variabel kontrol. Variabel dependen pada penelitian ini adalah rata-rata tertimbang dari excess return portofolio (Ri). Variabel independennya adalah rata-rata tertimbang dari risiko premium pasar (RpM). Variabel kontrol dari penelitian ini adalah selisih tingkat pengembalian saham antara perusahaan kecil dan perusahaan besar (SMB) dan selisih tingkat pengembalian saham antara perusahaan dengan book-to-market tinggi dan saham perusahaan dengan book-tomarket rendah (HML). Dalam permasalahan penelitian ini untuk mengukur kesejahteraan bidding ditunjukkan dengan nilai atau tanda konstanta dari model penelitian, bukan dari nilai atau tanda koefisien variabel independen.

\section{Variabel Dependen}

Rata-rata tertimbang dari excess return portofolio (Ri)

Rata-rata tertimbang dari excess return portofolio dihitung dari excess return individu perusahaan terlebih dahulu. Setelah dihitung excess retun individu perusahaan kemudian dihitung return portofolio untuk setiap periode atau waktu yang digunakan dalam penelitian ini adalah bulan. Berikut rumus dan tahap yang digunakan dalam menghitung rata-rata tertimbang dari excess return portofolio.

1. $\mathrm{ri}=$

2. $\mathrm{E}(\mathrm{Ri})=\mathrm{ri}-\mathrm{rf}$

3. $\mathrm{Ri}=\Sigma \mathrm{xi} \mathrm{E}(\mathrm{Ri})$

Dimana:

ri : return saham perusahaan $\mathrm{i}$

Pt : harga saham perusahaan pada $t$

Pt-1 : harga saham perusahaan pada $\mathrm{t}-1$

$\mathrm{E}(\mathrm{Ri})$ : excess return saham perusahaan $\mathrm{i}$

rf : tingkat bebas risiko (suku bunga Bank Indonesia)

$\mathrm{Ri}$ : rata-rata tertimbang dari excess return portofolio

xi : proporsi saham i pada portofolio

\section{Variabel Independen}

Rata-rata tertimbang dari risiko premium pasar (RpM)

Rata-rata tertimbang dari risiko premium pasar (RpM) dihitung dari selisih return pasar dan risk free. Return pasar dihitung menggunakan indeks harga saham gabungan (IHSG). Risk free merupakan tingkat bebas risiko yang diperoleh dari tingkat SBI.

\section{Variabel Kontrol}

Variabel kontrol yang digunakan salah satunya adalah selisih tingkat pengembalian saham antara perusahaan kecil dan perusahaan besar(SMB). Langkah pertama untuk menghitung SMB adalah menentukan ukuran perusahaan sampel. Perusahaan sampel dibedakan antara yang ukurannya besar dan ukurannya kecil. Setelah menentukan ukuran perusahaan dan menghitung tingkat pengembalian saham masing-masing perusahaan, yaitu menghitung selisih tingkat pengembalian saham antara perusahaan kecil dan perusahaan besar.

Variabel kontrol berikutnya adalah selisih tingkat pengembalian saham antara perusahaan dengan book-to-market tinggi dan saham perusahaan dengan book-to-market rendah (HML). Variabel kontrol ini didasarkan pada nilai book-to-market perusahaan sampel. Bookto-market merupakan rasio yang digunakan untuk menentukan nilai perusahaan dengan membandingkan nilai buku terhadap nilai pasar perusahaan. Nilai buku merupakan selisih antara total asset dan total hutang perusahaan. Sedangkan nilai pasar perusahaan merupakan harga saham dikalikan dengan jumlah saham beredar. Jika rasio dibawah satu, maka saham perusahaan overvalue. Jika rasio diatas satu, maka saham perusahaan undervalue. Setelah diperoleh rasio book-tomarket masing perusahaan dan return sahamnya, langkah terakhir adalah menselisihkan tingkat pengembalian saham antara perusahaan dengan book-to-market tinggi dan saham perusahaan dengan book-to-market rendah. 


\section{Analisis Data}

Analisis data berupa data time series dengan window event study sekitar 3 tahun (bulan ke 0 sampai 36) setelah pengumuman merger dan akuisisi. Jenis data yang digunakan dalam penelitian ini yaitu data sekunder dari perusahaan-perusahaan sampel yang memenuhi kriteria-kriteria yang disyaratkan. Penelitian ini menggunakan Ordinary Least Square (OLS) untuk mengestimasi persamaan model 1 dan diolah dengan Eviews 6. . Untuk memperoleh estimasi regresi yang baik dan menghindari adanya penyimpangan asumsi klasik pada penelitian, maka akan dilakukan uji diagnosis (uji ekonometrika) seperti uji stasioneritas (uji unit root), uji normalitas, uji linieritas, uji autokolerasi, homoskedastisitas, dan uji multikolinieritas.

\section{HASIL PENELITIAN DAN PEMBAHASAN}

Penelitian ini memiliki jumlah sampel sebanyak 28 perusahaan dengan tahun pengamatan dari tahun 2000 sampai tahun 2014. Jenis data penelitian ini adalah data time series sekitar 37 bulan sehingga memerlukan pengujian-pengujian variabel dan model sebelum melakukan pengujian hipotesis. Dari uji unit root dan pengujian asumsi klasik, terbukti bahwa variabel-variabel dalam model penelitian stasioner dan model tersebut terbebas dari pelanggaran asumsi klasik. Langkah selanjutnya adalah meregresi model penelitian untuk menguji hipotesis penelitian ini. Hasil regresi model penelitian ditunjukkan pada tabel 2.

Tabel 2 menyajikan hasil pengujian pengaruh merger dan akuisisi pada perusahaan bidder daam jangka panjang. Model penelitian yang diganakan yaitu: $\mathrm{Ri}_{\mathrm{t}}=\alpha+\beta \mathrm{RpM}_{\mathrm{t}}+\gamma$ $\mathrm{SMB}_{\mathrm{t}}+\delta \mathrm{HML}_{\mathrm{t}}+\mathrm{e}_{\mathrm{t}}$. dimana $\mathrm{Ri}$ adalah rata-rata tertimbang dari excess return portofolio, yang merupakan variabel dependen. $\alpha$ adalah konstanta yang mengukur nilai kesejahteraan bidder. RpM adalah rata-rata tertimbang dari risiko premium pasar. SMB adalah Selisih tingkat pengembalian saham antara perusahaan kecil dan perusahaan besar. HML Selisih tingkat pengembalian saham antara perusahaan dengan book-to-market tinggi dan saham perusahaan dengan book-to-market rendah.

Tabel 2

Hasil Pengujian Hipotesis

\begin{tabular}{|c|c|c|c|c|}
\hline Variabel & A & RpM & SMB & HML \\
\hline Koefisien & $-0,0432^{* *}$ & 1,5129 & 0,0474 & 0,0002 \\
\hline t-statistik & $-26,819$ & 3,9141 & 25,965 & 0,9817 \\
\hline Prob. & 0,0113 & 0,0004 & 0,0140 & 0,3334 \\
\hline
\end{tabular}

Sumber: hasil olah data (2016)

** signifikan pada $5 \%$

Penelitian ini bertujuan untuk menguji pengaruh merger dan akuisisi terhadap kesejahteraan pemegang saham bidder yang ditunjukkan pada nilai $\alpha$ dalam model 1. Nilai $\alpha$ atau konstanta (C) dari hasil regresi model 1 menujukkan tanda negatif dan signifikan secara statistik (one tailed, $\mathrm{t}_{\text {statistik }}<\mathrm{t}_{\text {tabel }}$ atau $-2,6819$ $<2,021)$. Hasil ini berkebalikan dengan tanda yang diharapkan dalam pengujian hipotesis penelitian ini, yaitu pengaruh yang positif dan signifikan secara statistik. Hal ini menunjukkan bahwa hipoesis yang diajukan dalam penelitian ini ditolak. Artinya merger dan akuisisi tidak memberikan kesejahteraan bagi pemegang saham perusahaan bidder dalam jangka panjang. Hasil penelitian ini sejalan dengan penelitian Moeller et al. (2005). Tanpa akuisisi, kesejahteraan pemegang saham perusahaan bidder akan meningkat. Perusahaan yang melakukan akuisisi mengalami kinerja yang buruk setelah keputusan tersebut. Sama dengan hasil penelitian Duchin \& Schmidt (2013), menemukan bahwa rata-rata kinerja jangka panjang dari agresif akuisisi selama gelombang merger secara signifikan buruk. Hasil-hasil penelitian sebelumnya mendukung hasil dalam penelitian ini. Rata-rata merger dan 
akuisisi di Indonesia dimotivasi dengan alasan yang tidak baik atau pengelolaan yang buruk sehingga tidak ada sinergi positif. Kemungkinan lain merger dan akuisis gagal dikarenakan gelombang merger memberikan niai yang semu pada kinerja perusahaan. Dilihat dari nilai koefisien HML yang dibawah satu menunjukkan saham perusahaan di Indonesia dinilai terlalu tinggi. Teori neoklasik juga menyatakan bahwa keputusan yang didasari dengan hal yang buruk akan menghasilkan kinerja yang buruk juga.

\section{KESIMPULAN DAN SARAN}

Merger dan akuisisi merupakan keputusan perusahaan yang diharapkan dapat memberikan manfaat bagi pihak-pihak yang bersangkutan. Banyak merger dan akuisisi dimotivasi karena halhal yang tidak baik, sepeti pemanfaatan kesalahan valuasi harga saham, kepentingan pribadi manajer dan semacamnya yang mengakibatkan merger dan akuisisi menjadi merugikan perusahaan, terutama pemegang saham bidder. Hasil penelitian ini menunjukkan bahwa merger dan akuisisi tidak memberikan manfaat bagi pemegang saham bidder dalam jangka panjang. Kemungkinan adanya faktor motivasi merger dan akuisisi yang tidak tepat tersebut yang mengakibatkan tidak adanya manfaat bagi pemegang saham bidder dalam jangka panjang. Penelitian selanjutnya dapat menguji faktor-faktor yang membuat tidak adanya manfaat bagi pemegang saham bidder. Sehingga kedepannya perusahaan dapat mengantisipasi dan menghindari keputusan yang dapat merugikan perusahaan.

Keterbatasan pada penelitian ini adalah jumlah perusahaan yang melakukan merger dan akuisisi di Indoesia serta sudah listing di BEI cukup terbatas. Sehingga pada penelitian ini memasukkan aktivitas merger dan akuisisi yang terjadi pada tahun krisis 2008. Kemungkinan masuknya pengamatan pada tahun tersebut membuat penelitian ini tidak dapat membuktikan pengaruh positif merger dan akuisisi pada perusahaan bidder. Penelitian selanjutnya dapat mengeluarkan pengamatan pada tahun krisis tersebut dan menambah jumlah sampel ke depannya. Saran lain untuk penelitian selanjutnya dapat juga menarik penelitian kualitatif dari keputusan merger dan akuisisi. Kinerja merger dan akuisisi dapat juga dilihat dari proses penggabungan budaya dari perusahaanperusahaan yang melakukan merger dan akuisisi. Jika proses penggabungan budaya ini sukses, maka kinerja perusahaan pun meningkat yang daoat dicerminkan dari kesejahteraan bidding. Hasil ke depannya diharapkan dapat lebih menguatkan pengaruh merger dan akuisisi terhadap kesejahteraan pemegang saham bidder di Indonesia. Saran untuk perusahaanperusahaan sebaiknya memutuskan merger dan akuisisi dilandasi dengan alasan yang logis dan tujuan yang baik. Keputusan merger dan akuisisi sebaiknya melalaui tahapan yang wajar, yaitu diawali dengan proses strategi. Strategi yang ditetapkan harus bertujuan meningkatkan kinerja perusahaan secara keseluruhan. Bukan strategi yang bertujuan untuk meningkatkan kepentingan pribadi agen perusahaan.

\section{DAFTAR PUSTAKA}

Ahern, K. R. \& Weston, J. F. 2007. "M\&As: The Good, the Bad, and the Ugly," Journal of Applied Finance.

Antoniou, A., Petmezas, D., \& Zhao, H. 2007. "Bidder Gains and Losses of Firms Involved in Many Acquisitions," Journal of Business Finance and Accounting, Vol. 34(7) \& (8).

Berkman, H. \& Eleswarapu, V. R. 1998. "Shortterm Traders and Liquidity: A Test Using Bombay Stock Exchange Data," Journal of Financial Economics, Vol. 47, 339-355.

Brigham, E. F. \& Houston, J. F. 2007. Essentials of Financial Management, Cengage Learning Asia Pte Ltd, Singapore. 
Duchin, R. \& Schmidt, B. 2013. "Riding the Merger Wave: Uncertainty, Reduced Monitoring, and Bad Acquisition," Journal of Financial Economics, 107, 69-88.

Fama, E. F. and French, K. R. 1993. "Common Risk Factors in the Return on Stocks and Bonds," Journal of Financial Economics, Vol. 33, 3-56.

Fuller, K., Netter, J. \& Stegemoller, M. 2002. "What Do Return to Acquiring Firms Tell Us? Evidence from Firms that Make Many Acquisitions," Journal of Finance, Vol. 57, 1763-1793.

Gorton, G., Kahl, M., \& Rosen, R. J. 2009. “Eat or Be Eaten: A Theory of Mergers and Firm Size," The Journal of Finance, Vol.LXIV, No.3.

Gujarati D.N. \& Poter, D. C. 2009. Basic Econometrics, $5^{\text {th }}$ edition, Mc-Graw Hill.

Hackbarth, D. \& Morellec, E. 2008. "Stock Returns in Mergers and Acquisitions," The Journal of Finance, Vol.LXIII, No.3.
Hanafi, M. M. 2004. Manajemen Keuangan, BPFE, Yogyakarta.

Mehrota, V., Schaik, D.V., Spronk, J., \& Steenbeek, O. 2011. "Creditor-Focused Corporate Governance: Evidence from Mergers and Acquisitions in Japan," Journal of Financial and Quantitative Analysis, Vol. 46, No.4, 1051-1072.

Moeller, S. B., Schilengemann, F. P. and Stulz, R. M. 2005. "Wealth destruction on a massive scale? A study of acquiringfirm returns in the recent merger wave," The Journal of Finance, Vol.LX, No.2.

Neuman, W. L. 2011. Social Research Methods, $7^{\text {th }}$ edition. Pearson.

Savor, P. G. \& Lu, Q. 2009. "Do Stock Mergers Create Value for Acquirers?" The Journal of Finance, Vol. LXIV, No.3.

Wang, C. \& Xie, F. 2009. "Corporate Governance Transfer and Synergistic Gains from Mergers and Acquisitions," The Review of Financial Studies, Vol. 22, No.2.

http://www.kppu.go.id/id/gelombang-mergermelanda-bangga-atau-waspada/ 25-052013, 14:15 WIB. 